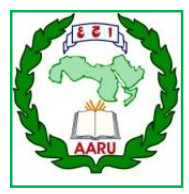

Arab Univ. J. Agric. Sci., Ain Shams Univ., Cairo, Egypt 28(1), 329-335, 2020

Website: http://ajs.journals.ekb.eq

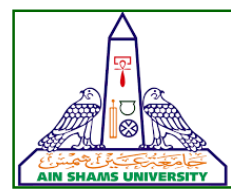

\title{
THE EFFECTIVENESS OF SOME PESTICIDES IN THE CONTROL OF THRIPS AND RED SPIDER MITES ON STRAWBERRY PLANTS
}

\author{
Eman M.M. Abdelmaksoud ${ }^{1 *}$, El-Refai ${ }^{1}$ S.A., Mahmoud ${ }^{1}$ K.W. \\ and Ragab ${ }^{2}$ M.E.
}

1- Plant Protection Dept., Fac. of Agric., Ain Shams Univ., P.O. Box 68, Hadayek Shoubra 11241, Cairo, Egypt

2- Horticulture Dept., Fac. of Agric., Ain Shams Univ., P.O. Box 68, Hadayek Shoubra 11241, Cairo, Egypt

*Corresponding author: prof emy2020@yahoo.com

Received 2 February, 2020

Accepted 19 March, 2020

\section{ABSTRACT}

This study was carried out in a private farm in Wardan, Giza governorate in Egypt during 2019 season on strawberry plants. The first experiment aimed to evaluate the effectiveness of different commercial products in cultivated land including Solo 24\% SC (Bifenazate), Arbus 12\% SC (Chlorfenapyr + Emamectin benzoate), Concor 24\% SC (Spirodiclofen), Excellent 1.9\% EC (Emamectin benzoate), Top9 (Chitosan 0.1\%), Biomectin 5\% EC (Abamectin) and Congest 15\% CS (Abamectin + Imidacloprid) in reducing the population densities of two spotted spider mite, Tetranychus uriticae Koch. on strawberry plants. According to general mean percentage of reduction in population of $T$. uriticae, data showed insignificant differences among the seven tested compounds whereas the mortality percentages were $85.94 \%, 82.18 \%, 81.4 \%, 79.36 \%$, $78.14 \%, 77.94 \%$ and $75.9 \%$, respectively. From these results; it's clear that Solo compound is the most effective compound and Congest is the lowest one. The other compounds ranged between them in controlling $T$. uriticae under these experimental conditions.

The second experiment evaluated the effectiveness of different formulations in the nursery including Radiant (Spinetoram 12\% Sc), Super Rigo (Naphthyl acetic acid - Chitosan), Top9 and Berna Star (Glyceryl stearate 32\%) in reducing the population densities of western flower thrips, Frankliniella occidentalis (Pergande) on strawberry plants. According to general mean percentage of reduction in population of $F$. occidentalis, data showed significant differences among the four compounds. These compounds could be divided into three groups. The first group contained Radiant compound showing high mortality (63.5\%). The second group contained Super Rigo and Top9 compounds showing moderate effect $(46.44 \% \& 34.3 \%)$, respectively. The third group contained Berna Star compound showing least effect (28.36\%). From these results; it's clear that the chemical compound Radiant is the most effective while the natural compound Berna Star is the lowest in controlling $F$. occidentalis under these experimental conditions.

Keywords: Frankliniella occidentalis, Tetranychus uriticae, Strawberry, Control.

\section{INTRODUCTION}

Western flower thrips, Frankliniella occidentalis (Pergande) (Thysanoptera: Thripidae) and Tetranychus uriticae Koch. (Acariformes: Tetranychidae) are serious pests infesting crops especially strawberry plants (Fragaria $\times$ ananassa Duchesne [Family: Rosaceae]. This causes substantial yield losses through direct feeding on the leaves and fruits which causes even greater loses for farmers and the economy. Insecticidestherefore, play an important role in the western flower thripscontrol and management. Yiğit and Erkiliç (1992) in Turkey, recommended using Azocyclotin, Bromopropylate, Dicofol and Dicofol Plus Tetradifon for controlling red spider mites. Hossain et al (2006) in Bangladesh, studied the effectiveness of four commonly used chemicals Viz., Malathion, Deltamethrin, Cypermethrin, and Sulphur against T. urticae on bean plants preserved and on excised leaf 
discs. Population of mite was significantly in all treated plots lower except malathion treatment. The $T$. urticae population differed significantly because of different chemicals and it stayed lower up to the $4^{\text {th }}$ week on plants that single-sprayed, which increased again. El-Sharabasy (2010) in Egypt, represented the potential of Artemisia judaica L. crude extracts that was evaluated for toxic and repellent effect against immature stage and adult females of T. urticae. Ethanolic leaf extraction was more effective as toxic and repellent effect against immature stage and adult females of $T$. urticae, followed by petroleum ether, acetone and aqueous extraction.

Rahman et al (2011) in USA, recorded that Spinosad is highly efficacious against $F$. occidentalis, and it's believed to be compatible in IPM program. These results suggest that the use of Camino Real with Spinosad applications can significantly reduce thrips populations. Abdallah et al (2014) in Egypt, controlled T. urticae with the biochemical compound Abamectin (Vapcomic) on kidney Bean (Paulista) and sugar snap pea (Snow wind) in a greenhouse at Behaira Governorate during 2013 season. The mean reduction percentage of the spider mite populations on both plant varieties by treating with Vapcomicwas (90.0\%). Abou El-Ela (2014) in Egypt, investigated five acaricides, Delmite, Challenger, Vertimec, Bioca and Ortus for the control of $T$. urticae of cotton seedlings. At the early seedling time late season during two successive seasons 2007\&2008. Results indicated that, Challenger is the most effective and Bioca is the least effective with $82.3 \%$ and $55.1 \%$ approximate reduction respectively during two successive seasons. Golmohammadi and Mohammadipour (2015) in Iran, studied five treatments and four replications on Frankliniella occidentalis in the greenhouses. The treatments were as follows: Pyrethrum, Dichlorvos, Azadirachtin, Flonicamid and control. The new insecticide and the herbal extracts, Flonicamid had acceptable control against the thrips of strawberry in the greenhouse. Bi et al (2016) in USA, determined the resistance status of these two pest species Tetranychus cinnabarinus (Boisduval) and Tetranychus urticae to commonly used chemical acaricides on strawberries as Abamectin, Spiromesifen, Etoxazole, Hexythiazox and Bifenazate. Results suggest $T$. urticae have developed resistance to Hexythiazox and that the $T$. cinnabarinus have developed resistance to Bifenazate. Gholami and Sadeghi (2016) in Iran, recorded that mechanical, cultural, biological and chemical controls are the main strategies of the IPM program for thrips. The insecticides play an im- portant role in the western flower thrips management. Pyridalyl, Spinosad, and botanical insecticides such as Azadirachtin and Oxymatrine are new and effective insecticides for controlling $F$. occidentalis. Renkema et al (2018) in Florida, carried out an experiment to compare Sulfoxaflor, Spinetoram, and the entomopathogenic nematode, Steinernema feltiae (Filipjev) applications based on thresholds of flower thrips. High and low $S$. feltiae rates did not reduce thrips and fruit damage. Sulfoxaflor reduced thrips by 60 to $70 \%$ compared to the Spinetoram reduction. Dry, hot, conditions likely limited effectiveness and the survival of $S$. feltiae. Sulfoxaflor appears to be a promising insecticide for flower thrips and may reduce reliance the strawberry producers on Spinetoram.

Therefore, this study aimed to determine the effectiveness of some formulations available in the local market for the control of strawberry pests.

\section{MATERIALS AND METHODS}

\section{The effectiveness of control agents against Tetranychus uriticae in the production land}

To study the effectiveness of the tested products on the population of $T$. uriticae infesting strawberry variety Festival, the area of this experiment was about $\left(1100 \mathrm{~m}^{2}\right)$, divided into 24 plots (each treatment replicated 3 times) for 7 treatments in addition of the control (Table 1). Strawberry plants were treated on $9^{\text {th }}$ of March during season 2019 in the production land.

\section{The effectiveness of control agents against Frankliniella occidentalis in the nursery}

The other experiment to study the effectiveness of the tested products on the population of $F$. occidentalis infesting strawberry variety Festival, the area of this experiment was about $\left(750 \mathrm{~m}^{2}\right)$, divided into 15 plots (each treatment replicated 3 times) for 4 treatments in addition of the control (Table 2). Strawberry plants were treated on $14^{\text {th }}$ of July during season 2019 in the nursery.

The replicates were distributed in a complete randomized block design. A knapsack sprayer was used and filled with that prepared concentration just before each treatment. Spraying was done by using a motor sprayer of 20-L capacity. Inspection of plants was carried out before spraying (zero time) and after 1, 3, 5, 7, 10 and 14 days after application. 
Table 1. Insecticides used against Tetranychus uriticae on Strawberry plants at Wardan, Giza governorate on spring 2019

\begin{tabular}{|l|l|l|l|}
\hline \multicolumn{1}{|c|}{ Trade name } & \multicolumn{1}{|c|}{ Common name } & \multicolumn{1}{c|}{ Chemical class } & Rate/L.water \\
\hline Concor 24\% SC & Spirodiclofen & Tetronic acid & $30 \mathrm{~cm}^{3} / 100 \mathrm{~L}$ \\
Solo24\% SC & Bifenazate & Carbazate & $75 \mathrm{~cm}^{3} / 100 \mathrm{~L}$ \\
Arbus $12 \%$ SC & Chlorfenapyr + Emamectin benzoate & Pyrrole +Avermectin & $2 \mathrm{~cm}^{3} / 100 \mathrm{~L}$ \\
Excellent 1.9\%EC & Emamectin benzoate & Avermectin & $70 \mathrm{~cm}^{3} / 200 \mathrm{~L}$ \\
Congest15\% CS & Abamectin + Imidacloprid & Avermectin+Neonicotinoid & $35 \mathrm{~cm}^{3} / 100 \mathrm{~L}$ \\
Biomectin 5\%EC & Abamectin & Avermectin & $20 \mathrm{~cm}^{3} / 100 \mathrm{~L}$ \\
Top9 & Chitosan 0.1\% & shrimp shell waste extract & $1000 \mathrm{~cm}^{3} / 200 \mathrm{~L}$ \\
\hline
\end{tabular}

Table 2. Insecticides used against Frankliniella occidentalis on Strawberry plants at Wardan, Giza governorate season 2019.

\begin{tabular}{|c|c|c|c|}
\hline Trade name & Common name & Chemical class & Rate/L. water \\
\hline Radiant & Spinetoram $12 \%$ Sc & $\begin{array}{l}\text { Fermentation product of } \\
\text { Saccharopolyspora spinosa, } \\
\text { an analogue Spinosad \& a spinosyn }\end{array}$ & $120 \mathrm{~cm}^{3} / 200 \mathrm{~L}$ \\
\hline Super Rigo & Naphthyl acetic acid - Chitosan & Plant extract (botanical) & $125 \mathrm{~cm}^{3} / 100 \mathrm{~L}$ \\
\hline Berna Star & Glyceryl stearate $32 \%$ & Plant extract (botanical) & $1000 \mathrm{~cm}^{3} / 200 \mathrm{~L}$ \\
\hline Top9 & Chitosan $0.1 \%$ & Shrimp shell waste extract & $1000 \mathrm{~cm}^{3} / 200 \mathrm{~L}$ \\
\hline
\end{tabular}

Sample size was 30 leaves (3/replicates). The observation of pests was carried out in the field followed by laboratory examination by inspecting 10 leaves picked at random and examined primarily by a pocket lens in the field, then transferred to the laboratory in paper pages to examine by the aid of stereomicroscope. The reduction percentages were calculated according to the equation of Henderson and Tilton (1955).

Where:

$$
\% \text { Reduction }=\left(1-\frac{T a * C b}{T b * C a}\right) * 100
$$

$\mathbf{T}_{\mathrm{a}}=$ number of insects or mites after treatments.

$\mathbf{T}_{\mathbf{b}}=$ number of insects or mites before treatments .

$\mathbf{C}_{\mathrm{a}}=$ number of insects or mites after in control.

$\mathbf{C}_{\mathbf{b}}=$ number of insects or mites in control before.

For testing homogeneity of control agents, $x^{2}$ method was used (Snedecor and Cochran 1987).

$$
X^{2}=\sum\left(a i{ }^{*} p i\right)-C 1^{*} \bar{P} i / \bar{P} i^{*} \bar{q}
$$

Whereas $\overline{\mathrm{P}} \mathrm{i}=\mathrm{C} 1 / \mathrm{G}$

$$
\overline{\mathrm{q}}=1-\overline{\mathrm{P}} \mathrm{i}
$$

\section{RESULTS AND DISCUSSION}

1. The effectiveness of control agents against Tetranychus uriticae in the production land

The effectiveness of different chemical compounds included Concor 24\% SC, Solo 24\% SC, Arbus $12 \%$ SC, Excellent 1.9\%EC, Congest 15\% CS, Biomectin 5\% EC, and Top9 in reducing the population densities of $T$. uriticae on strawberry plants were assayed after receiving one spray of each compound during the experimental period, the results of these field experiments are tabulated in Table (3 and 4).

According to general mean percentage of reduction in population of $T$. uriticae, data in Table (4) indicated that there are insignificant differences between the seven compounds whereas $x^{2}=3.75$ insig. So, the cheaper compound is the best choice. The mortality percentages were $85.94 \%, 82.18 \%$, $81.4 \%, 79.36 \%, 78.14 \%, 77.94 \%$ and $75.9 \%$, for compounds Solo, Arbus, Concor, Excellent, Top9, Biomectin and Congest, respectively. From these 
results; it's clear that Solo compound is the most effective compound and Congest is the lowest one. The other compounds ranged between them in controlling $T$. uriticae under these experimental conditions.
The results obtained are in harmony with those previously reported by Yiğit and Erkiliç (1992) in Turkey; Hossain et al (2006) in Bangladesh; ElSharabasy (2010) in Egypt; Abdallah et al (2014) in Egypt; Abou El-Ela (2014) in Egypt and Bi et al (2016) in USA.

Table 3. General mean percentage reduction in mean number of Tetranychus uriticae on strawberry plants at Wardan, Giza governorate spring 2019

\begin{tabular}{|l|c|c|c|c|c|c|}
\hline Product & 1 day & 3days & 5days & 7days & 14days & General mean \\
\hline Concor & 61.9 & 69.3 & 87.9 & 87.9 & 100 & 81.4 \\
Solo & 62.6 & 82.3 & 92.4 & 92.4 & 100 & 85.94 \\
Arbus & 45.6 & 84.3 & 89.9 & 91.1 & 100 & 82.18 \\
Excellent & 49.1 & 77.7 & 83.4 & 86.6 & 100 & 79.36 \\
Congest & 49.1 & 59.3 & 85.1 & 86 & 100 & 75.9 \\
Biomectin & 58.9 & 71.7 & 79.3 & 79.8 & 100 & 77.94 \\
Top9 & 49.1 & 81.8 & 80.4 & 79.4 & 100 & 78.14 \\
\hline
\end{tabular}

Table 4. Chi square $\left(\mathrm{X}^{2}\right)$ analysis for the change by the infestation of Tetranychus uriticae on Strawberry plants at Giza governorate on spring 2019.

\begin{tabular}{|l|c|c|c|c|}
\hline \multicolumn{1}{|c|}{ Product } & $\begin{array}{c}\% \text { corrected } \\
\text { (ai) }\end{array}$ & $\begin{array}{c}\mathbf{R} \\
\mathbf{1 0 0 \%}\end{array}$ & $\begin{array}{c}\mathbf{P i} \\
(\mathbf{a i} / \mathbf{R})\end{array}$ & ai Pi \\
\hline Solo & 85.94 & 100 & 0.859 & 73.8 \\
Arbus & 82.18 & 100 & 0.821 & 67.5 \\
Concor & 81.4 & 100 & 0.814 & 66.3 \\
Excellent & 79.36 & 100 & 0.793 & 62.9 \\
Top9 & 78.14 & 100 & 0.781 & 61 \\
Biomectin & 77.94 & 100 & 0.779 & 60.7 \\
Congest & 75.9 & 100 & 0.759 & 57.6 \\
\hline Total & $\mathrm{C} 1=560.8$ & $\mathrm{G}=700$ & 5.6 & 449.8 \\
\hline
\end{tabular}

$x^{2}=3.75$ non sig.

2. The effectiveness of control agents against Frankliniella occidentalis in the nursery

The effectiveness of different chemical compounds included Radiant, Super Rigo, Berna Star and Top9 in reducing the population densities of $F$. occidentalis on strawberry plants were assayed received one spray of each compound during the experimental period, the results of these field experiments are tabulated in Table (5 and 6).

According to general mean percentage of reduction in population of $F$. occidentalis data in Table (6), there were significant differences among the four compounds whereas $x^{2}=29.5$ at 0.01 . These compounds could be divided to three groups. The first group contained on Radiant showing high mortality (63.5\%). The second group contained on Super
Rigo and Top9 showing moderate effect (46.44\%\& $34.3 \%)$, respectively. The third group contained on Berna Star showing least effect (28.36\%). From these results; it's clear that the chemical compound Radiant is the most effective while the natural compound Berna Star is the lowest in controlling F. occidentalis under these experimental conditions.

These results are in line with Rahman et al (2011) in USA; Golmohammadi and Mohammadipour (2015) in Iran; Gholami and Sadeghi (2016) in Iran and Renkema et al (2018) in Florida.

Further work can be carried out to determine which pesticides are better to use especially when there is no significant difference in their effectiveness, this includes residual effect as well as comparison of $\mathrm{PHI}$. 

spider mites on strawberry plants

Table 5. General mean percentage of reduction in mean number of Frankliniella occidentalis on strawberry plants at Wardan, Giza governorate on summer 2019

\begin{tabular}{|l|c|c|c|c|c|c|}
\hline Product & 1 day & 3days & 5days & 7days & 14 days & General mean \\
\hline Radiant & 20 & 45 & 63.3 & 89 & 100 & 63.5 \\
Super Rigo & 9.1 & 25.6 & 33.3 & 70 & 94.2 & 46.44 \\
Top9 & 0 & 1 & 14.4 & 56 & 100 & 34.3 \\
Berna Star & 0 & 1 & 2.2 & 45 & 93.6 & 28.36 \\
\hline
\end{tabular}

Table 6. Chi square $\left(\mathrm{X}^{2}\right)$ analysis for the change by the infestation of $F$. occidentalis on Strawberry plants at Wardan, Giza governorate on summer 2019

\begin{tabular}{|l|c|c|c|c|c|}
\hline Product & $\begin{array}{c}\% \text { corrected } \\
\left(\mathbf{a}_{\mathbf{i}}\right)\end{array}$ & $\begin{array}{c}\mathbf{R} \\
\mathbf{1 0 0 \%}\end{array}$ & $\begin{array}{c}\mathbf{P}_{\mathbf{i}} \\
\left(\mathbf{a}_{\mathbf{i}} / \mathbf{R}\right)\end{array}$ & $\mathbf{a}_{\mathbf{i}} \mathbf{P}_{\mathbf{i}}$ & \\
\hline Radiant & 63.5 & 100 & 0.635 & 40.3 & $\mathrm{a}$ \\
Super Rigo & 46.44 & 100 & 0.464 & 21.5 & $\mathrm{~b}$ \\
Top9 & 34.3 & 100 & 0.343 & 11.8 & $\mathrm{C}$ \\
Berna star & 28.36 & 100 & 0.284 & 8.1 & \\
\hline Total & $\mathrm{C}_{1=172.6}$ & $\mathrm{G}=400$ & 1.726 & 81.7 & \\
\hline
\end{tabular}

$\mathrm{X}^{2}=29.5$ sig. at 0.01

\section{ACKNOWLEDGEMENT}

The writers express their deep thanks to Prof. Dr. El-Sayed, W.A., Dept. of Plant Protection, Fac. of Agric., Ain Shams Univ. for helping during this work.

\section{REFERENCES}

Abdallah A.A., Al-Azzazy M.M., Mowafi M.H., ElSaiedy E.M.A. and Pastawy M.A. 2014. Control of the Two-Spotted Spider Mite, Tetranychus urticae Koch on kidney Bean and Pea Plants. ACARINES, 8(1), 43-48.

Abou El-Ela A.A. 2014. Efficacy of five acaricides against the two-spotted spider mite Tetranychus urticae Koch and their side effects on some natural enemies. J. Basic \& Appl. Zool., 67(1), 1318.

Bi J.L., Niu Z.M., Yu L. and Toscano N.C. 2016. Resistance status of the carmine spider mite, Tetranychus cinnabarinus and the two-spotted spider mite, Tetranychus urticae to selected acaricides on strawberries. Insect Sci., 23, 88-93.
El-Sharabasy H.M. 2010. Acaricidal activities of Artemisia judaica L. extracts against Tetranychus urticaeKoch and its predator Phytoseiulus persimilis AthiasHenriot (Tetranychidae: Phytoseiidae). J. Biopesticides, 3(2), 514 -519.

Gholami Z. and Sadeghi A. 2016. Management Strategies for Western Flower Thrips in Vegetable Greenhouses in Iran: a Review. Plant Protect. Sci., 52(2), 87-98.

Golmohammadi G. and Mohammadipour A. 2015. Efficacy of herbal extracts and synthetic compounds against strawberry thrips, Frankliniella occidentalis (Pergande) under greenhouse conditions. J. Entomol. Zool. Studies, 3(4), 4244.

Henderson C.F. and Tilton E.W. 1955. Test with acaricides against the brown wheat mite. J. Econ. Entomol., 48, 157-161.

Hossain S., Haqueand M. and Nader N. 2006. Control of two-spotted spider mite Tetranychus urticae Koch. (Acari: Tetranychidae) by some selected chemicals. Univ. J. Zool., Rajshahi Univ., 25, 15-18. 
Rahman T., Broughton S. and Spafford H. 2011. Effect of spinosad and predatory mites on control of Frankliniella occidentalis in three strawberry cultivars. Entomol. Experiment. et Appl., 138, 154-161.

Renkema J.M., Evans B. and Devkota S. 2018. Management of flower thrips in Florida strawberries with Steinernema feltiae (Rhabditida: Steinernematidae) and the insecticide sulfoxaflor. Florida Entomol., 101(1), 102-108.
Snedecor G.W. and Cochran W.G. 1987. Statistical methods, $7^{\text {th }}$ printing, The lowa State University Press, Ames, lowa, USA.

Yiğit A. and Erkiliç L. 1992. Studies on the chemical control of Tetranychus cinnabarinus boisd. (Acarina: Tetranychidae), a pest of strawberry in the East Mediterranean region of Turkey. J. Crop Protection., 11(5), 433-438. 


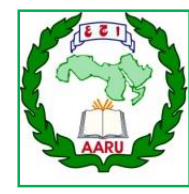

مجلة اتحاد الجامعات العربية للعلوم الزراعية، جامعة عين شمس، القاهرة، مصر مجلد(28)، عدد(1)، 335-329، 2020

Website: http://ajs.journals.ekb.eg

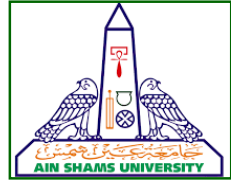

تقييم كفاءة بعض المبيدات في مكافحة التربس والعنكبوت الأحمر علي نباتات الفراولة

$$
\begin{aligned}
& \text { إيمان محمد محمد عبدالمقصود1" - شكري أحمد الرفاعي1 - قدري وشاحي محمود1 - } \\
& \text { محمد إمام رجب } \\
& \text { 1- قسم وقاية النبات - كلية الزراعة - جامعة عين شمس - ص.ب 68- حدائق شبرا } 11241 \text { - القاهرة - مصر } \\
& \text { 2- قسم البساتين - كلية الزراعة - جامعة عين شمس - ص.ب 68- حدائق شبرا } 11241 \text { - القاهرة - مصر }
\end{aligned}
$$

*Corresponding author: prof emy2020@yahoo.com

التجربة الثانية أجريت لتقييم كفاءة المركبات المختلفة

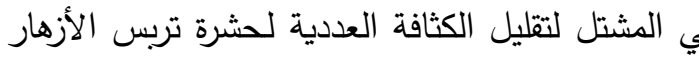

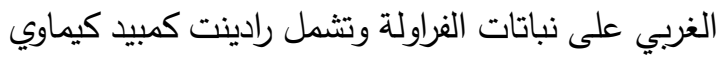

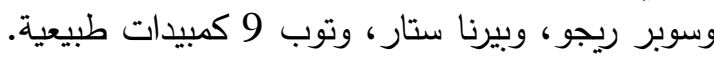
وفقا للنسبة المئوية العامة للانخفاض في تعداد التربس، وتربك،

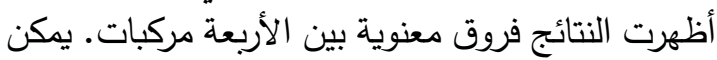

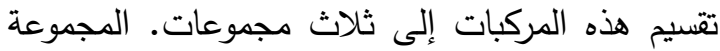

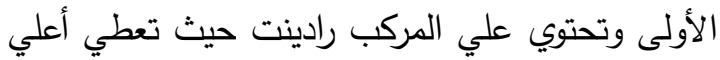

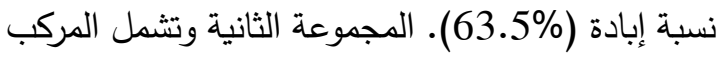
سوبر ريجو وتوب9 الذبادة (63.5\%) الذي أعطي نسبة إبادة متوسطة

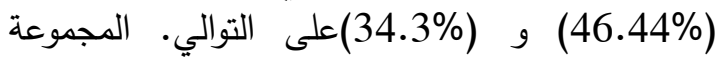
الثالثة وتثمل المركب بيرنا ستار حيث أعطي أقل نسبة التبال

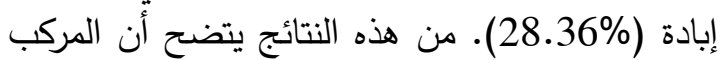

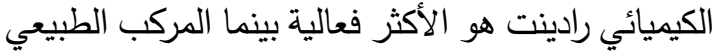

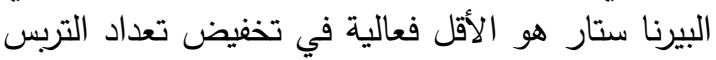
تحت ظروف هذه التجربة.

الكلمات المفتاحية: تربس الأزهار الغربي، العنكبوت

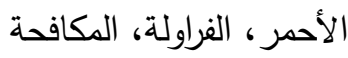

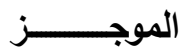

أجريت هذه الدراسة في واردان بمحافظة الجيزة في

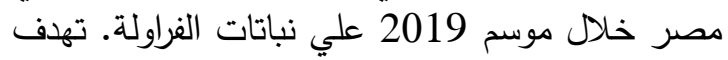
التجربة الأولي إلي تقييم كفاءة مختلف المركبات التجارية

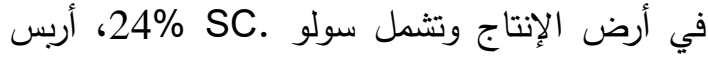
12\% SC

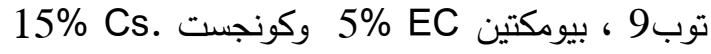
لتقليل الكثافة العددية للعنكبوت الأحمر علي تلبي نباتات الفراولة. وفقاً للنسبة المئوية العامة لتخفيض العندية أعداد

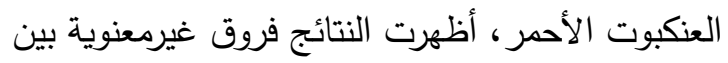

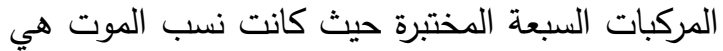

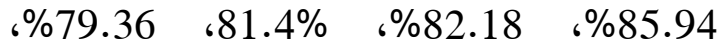

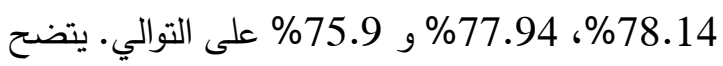
من هذا أن المركب الكيميائي سولو هو المركب الأكثر

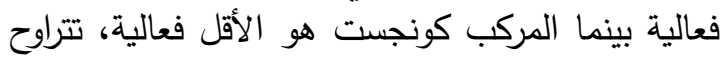

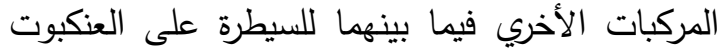
تحت ظروف هذه التجربة. 